\title{
KUALITAS PENDIDIKAN SEBAGAI MOTOR PENGERAK PEREKONOMIAN PERTUMBUHAN EKONOMI DI JAWA TIMUR
}

\author{
*(Abid Muhtarom \\ Fakultas Ekonomi \\ Universitas Islam Lamongan
}

\begin{abstract}
ABTRAKSI
Berdasarkan kontradiksi pendapat pertumbuhan ekonomi yang berada di atas pertumbuhan ekonomi nasional. Pada tahun 2009 pertumbuhan ekonomi di Jawa Timur sebesar 5,01\% sedangkan pertumbuhan ekonomi nasional sebesar 4,55\%, dan pada tahun 2010 pertumbuhan ekonomi di Jawa Timur sebesar 6,68\% dan nasional sebesar 6,10\%. Kualitas dan kuantitas tenaga kerja merupakan suatu faktor yang mempengaruhi output suatu daerah. Jumlah penduduk yang besar, khususnya penduduk dengan usia produktif, akan meningkatkan jumlah angkatan kerja yang tersedia. Jumlah tenaga kerja yang besar disertai dengan kualitas pendidikan yang Tantangan utama pendidikan di Jawa Timur adalah bagaimana meningkatkan kualitas sumber daya manusia. Peningkatan kualitas sumber daya manusia adalah salah satu cara untuk meningkatkan produktivitas. Sekitar 55 persen dari tenaga kerja di Jawa Timur hanya mengecap pendidikan Sekolah Dasar. Hal ini juga ditunjukkan oleh angka partisipasi murni (APM) sekolah yang semakin menurun pada tingkat SMP dan SMA.Hasil Survei Angkatan Kerja Nasional yang dilaksanakan pada Agustus 2009 diketahui bahwa pekerja di Jawa Timur mengalami peningkatan sebesar 442,8 ribu orang dibandingkan Agustus 2008. Sejalan dengan peningkatan jumlah pekerja tersebut, maka jumlah pengangguran mengalami penurunan sebesar 262,8 ribu orang (25,43 persen). Penyerapan tenaga kerja perempuan selama Agustus 2008 - Agustus 2009, lebih besar dibandingkan dengan laki-laki, yaitu masing-masing jumlah pekerja perempuan meningkat 228,6 ribu orang dan pekerja laki-laki meningkat sebesar 194,2 ribu orang. Namun demikian, dominasi peningkatan penduduk perempuan yang bekerja umumnya hanya sebagai pekerja keluarga., sehingga peningkatan jumlah tenaga kerja tidak selalu memberikan implikasi yang positif terhadap peningkatan pendapatan pekerja, karena penambahan jumlah tenaga kerja hanya terserap sebagai pekerja keluarga atau membantu rumahtangga/suami dalam melakukan kegiatan ekonomi yang sifatnya informal. Lebih lanjut, jika melihat status pekerjaan berdasarkan klasifikasi formal dan informal, maka pada Agustus 2009 sekitar 73,12 persen tenaga kerja bekerja pada kegiatan informal (Pemprov jatim, 2010).
\end{abstract}

\section{Kata kunci : kualitas pendidikan, motor penggerak perekomian,pertumbuhan ekonomi}

\section{PENDAHULUAN}

Dalam studi makroekonomi, kenaikan output dapat dianalisis menjadi dua bagian, yaitu studi dalam jangka panjang dan studi dalam jangka pendek. Dalam jangka panjang kenaikan output dapat dipengaruhi oleh tekhnologi dan input faktor produksi. Seperti kapital dan tenaga kerja. Investasi akan meningkatkan jumlah kapital, Sehingga adanya tambahan kapital tentu saja akan meningkatkan ketersediaan lapangan kerja yang kemudian dapat memicu peningkatan output nasional (Mubyarto,2003). Namun, faktor kunci yang paling berpengaruh terhadap kenaikan output nasional adalah kemajuan tekhnologi. Hal ini karena kemajuan tekhnologi dapat menigkatkan output pada tingkat kapital dan tenaga kerja yang tetap. 
Banyaknya tenaga kerja yang ada di Provinsi Jawa Timur sebagian besar tergolong sebagai unskilled labor atau tenaga kerja tidak terdidik. Tenaga kerja tidak terdidik adalah tenaga kerja kasar yang hanya mengandalkan tenaga saja. Contoh: kuli, buruh angkut, pembantu rumah tangga, dan sebagainya. Tingginya angka unskilled labor menunjukkan bahwa kualitas tenaga kerja di Jawa Timur masih rendah.

Berbagai upaya telah dilakukan oleh pemerintah untuk bisa meningkatkan kualitas tenaga kerja di Jawa Timur. Mengingat tingginya jumlah tenaga kerja yang terserap lebih banyak pada sektor informal. Sektor informal memang menawarkan peluang kerja yang lebih fleksibel dalam hal persyaratan namun lemah dalam hal jaminan keberlangsungan pekerjaan tersebut (job security). Pekerja sektor informal rentan terhadap gejolak ekonomi dan cenderung tidak menentu penghasilannya khususnya para pekerja bebas (pekerja tidak tetap) yang hanya bekerja sesekali saja dan berpindah-pindah majikan maupun jenis pekerjaannya. Pekerja sektor informal juga umumnya tidak dilindungi oleh fasilitas kesehatan, perlindungan kecelakaan, maupun jaminan pensiun.

Banyaknya tenaga kerja dengan jenjang pendidikan SD jumlahnya lebih besar dibandingkan dengan jenjang pendidikan yang lain. Tahun 1994 banyaknya tenaga kerja berpendidikan SD sebesar 10.639 .450 orang, berpendidikan SMP sebanyak 3.184.050 orang, dan yang mempunyai pendidikan SMA/MA/SMK sebanyak 2.863.691 orang. Banyaknya tenaga kerja yang mempunyai pendidikan diploma, sarjana (S-1), pasca sarjana (S-2) dan doktor (S-3) jauh lebih sedikit lagi yaitu hanya sebesar 256.535orang. Dengan demikian secara umum rata-rata tenaga kerja tahun 1994 mempunyai rata-rata lama pendidikan sebesar 7,73 tahun.

Seiring berjalannya waktu pemerintah mulai menggalakkan berbagai macam program pendidikan untuk meningkatkan kualitas tenaga kerja. Program-program tersebut berimbas pada kenaikan jumlah tenaga kerja yang mempunyai jenjang pendidikan menengah, diploma dan sarjana yang hal tersebut berarti penurunan banyaknya tenaga kerja yang mempunyai pendidikan SD dan SMP. Pada tahun 2009, banyaknya tenaga kerja berpendidikan SD sebesar 11.155.876 orang, berpendidikan SMP sebanyak 3.373.215 orang, dan yang mempunyai pendidikan SMA/MA/SMK sebanyak 3.652.437 orang. Banyaknya tenaga kerja yang mempunyai pendidikan diploma, sarjana (S-1), pasca sarjana (S-2) dan doktor (S-3) jauh lebih sedikit lagi yaitu hanya sebesar 323.774 orang. Dengan demikian secara umum rata-rata tenaga kerja tahun 2009 mempunyai ratarata lama pendidikan sebesar 7,95 tahun.

Kompleksitas

permasalahan ketenagakerjaan secara umum masih ditandai relatif rendahnya kualitas tenaga kerja, baik dari segi pendidikan formal maupun keterampilannya. Akibatnya, tingkat produktivitas tenaga kerja menjadi rendah, sehingga posisi tawar (bargaining position) menjadi rendah; tingkat upah yang rendah; sering terjadinya perselisihan hubungan industrial, dan pemutusan hubungan kerja (PHK), serta rendahnya jaminan kesejahteraan purna-kerja.

Pada sisi lain, perkembangan tuntutan pasar kerja dan persaingan industri di pasar global, di mana penggunaan teknologi dan informasi sebagai unggulan di samping faktor ekonomis, menuntut kebutuhan tenaga kerja profesional yang memenuhi standar kualifikasi tenaga kerja berbasis knowledge, skill dan attitude (KSA), serta keterampilan sosial (social skill). Pasar kerja di masa datang juga menuntut adanya jaminan kondisi iklim ketenagakerjaan yang kondusif, harmonis dan dialogis, yang melahirkan suasana hubungan industrial yang ramah, dan adanya kepastian hukum dalam usaha dan investasi.

Kualitas tenaga kerja berpengaruh positif terhadap pertumbuhan ekonomi. 
Artinya, ketika kualitas tenaga kerja semakin meningkat, maka akan dapat memacu pertumbuhan ekonomi di Jawa Timur. Jawa Timur memiliki angkatan kerja tingkat provinsi yang paling besar di Indonesia, dan dapat dianggap sebagai provinsi dengan "surplus tenaga kerja", terutama bagi industri-industri padat karya yang membutuhkan keterampilan yang rendah. Investasi padat karya dapat memanfaatkan kelompok pekerja dalam jumlah yang besar dengan tingkat keterampilan menengah, yaitu mereka yang setidaknya memiliki pendidikan sekolah menengah. Tingkat pengangguran bagi angkatan kerja dengan pendidikan sekolah menengah ke atas kini berada pada 11.3 persen, yang menunjukkan bahwa pasar tenaga kerja masih jauh dari jenuh. Jawa Timur juga memiliki salah satu tingkat upah minimum dan rata-rata upah bulanan yang paling rendah dibanding seluruh provinsi-provinsi lain di Indonesia. Nilai upah premium untuk mempekerjakan seorang pekerja terampil juga lebih rendah dibanding sebagian besar daerah. Demikian kenaikan kualitas tenaga kerja di Jawa Timur akan dapat mendorong pertumbuhan ekonomi.

Selain tenaga kerja, faktor kualitas tenaga kerja yang bagus juga mempunyai peran penting dalam mendorong pertumbuhan ekonomi di Jawa Timur. Hal ini karena sumber daya manusia yang produktif merupakan penggerak pertumbuhan ekonomi. Untuk menghasilkan tenaga kerja yang produktif, maka diperlukan pendidikan yang bermutu dan relevan dengan kebutuhan pembangunan. Dalam ekonomi yang semakin bergeser ke arah ekonomi berbasis pengetahuan, peran pendidikan tinggi sangat penting, antara lain untuk menghasilkan tenaga kerja yang unggul dan produktif, yang semakin mampu menerapkan ilmu pengetahuan dan teknologi yang dibutuhkan, untuk meningkatkan nilai tambah kegiatan ekonomi yang berkelanjutan. Pendidikan tinggi di sini terdiri dari program pendidikan akademik, program pendidikan vokasi, serta program pendidikan profesi.

\section{METODE PENELITIAN}

Di Jawa Timur perkembangan kualitas tenaga kerja menunjukkan trend yang terus meningkat terutama pada tahun 2010. Hal ini tidak terlepas dari sistem pendidikan di Jawa Timur yang mulai menuju penyelarasan bidang dan program studi dengan potensi pengembangan ekonomi di setiap koridor ekonomi. Meskipun belum maksimal, akan tetapi mulai menunjukkan hasil yang positif. Kegiatan pokok yang telah dilaksanakan oleh Pemrintah Provinsi dan Daerah di Jawa Timur dalam hal peningkatan kualitas tenaga kerja antara lain adalah sebagai berikut:
1. Pengembangan standar kompetensi kerja dan sistem sertifikasi kompetensi tenaga kerja.
2. Penyelenggaraan program- program pelatihan kerja berbasis kompetensi.

3. Peningkatan dan fasilitasi pelaksanaan uji kompetensi yang terbuka bagi semua tenaga kerja.

4. Peningkatan relevansi dan kualitas lembaga pelatihan kerja, serta peningkatan profesionalisme tenaga kepelatihan dan instruktur pelatihan kerja.

5. Fasilitasi peningkatan sarana dan prasarana lembaga latihan kerja.

6. Meningkatkan pendidikan dan latihan bagi calon tenaga kerja migran (TKI/TKW).

\section{PEMBAHASAN}

Selain itu, sistem pendidikan di Jawa Timur juga mengakomodasi program pendidikan vokasi untuk menghasilkan lulusan yang terampil. Pengembangan program pendidikan vokasi disesuaikan dengan potensi di masing- masing koridor ekonomi. Di setiap kabupaten/ kota, 
dikembangkan pendidikan tinggi setingkat akademi (community college) atau politeknik dengan bidang-bidang yang sesuai dengan potensi di kabupaten tersebut. Pengembangan community college, yang menyelenggarakan program diploma 1, diploma 2 dan diploma 3, diharapkan akan menghasilkan lulusan yang langsung dapat diserap oleh kegiatan ekonomi di pusat-pusat pertumbuhan ekonomi di setiap koridor ekonomi. Karena itu, pengembangan community college dilakukan dengan secara bersamasama antara pemerintah, dunia usaha, dan universitas sebagai pengelola community college. Mutu community college dibina oleh politeknik yang dikembangkan di ibukota provinsi. Politeknik tersebut dikembangkan sesuai dengan potensi dan keunggulan setiap koridor ekonomi.

Selain pengembangan pendidikan tinggi, pengembangan sumber daya manusia juga dilakukan dengan pengembangan pendidikan Sekolah Menengah Kejuruan (SMK), pengembangan pelatihan kerja, dan pengembangan lembaga sertifikasi. Berikut adalah model berbagai dan terintegrasi pendidikan tinggi dan menengah di Jawa Timur.

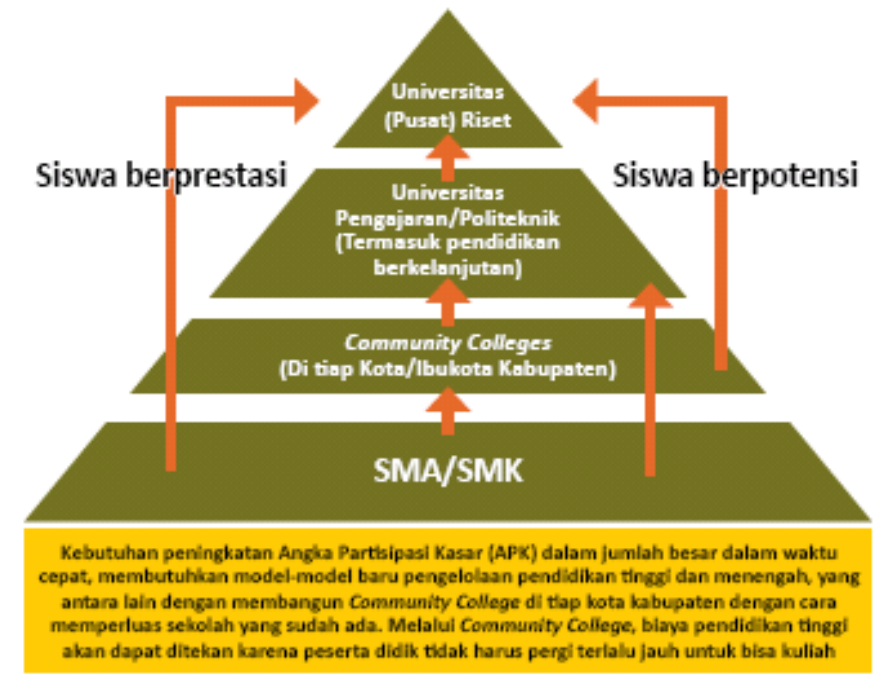

\section{Model Berbagai Dan Terintegrasi Pendidikan Tinggi Dan Menengah Di Jawa Timur.}

Sumber: Masterplan Percepatan Dan Perluasan Pembangunan Ekonomi Indonesia 2011-2025

Namun demikian, fakta juga menunjukkan bahwa secara kuantitas banyaknya unskilled labor masih lebih besar dibanding dengan skilled labor. Besarnya unskilled labor di Jawa Timur bisa menjadi penghambat bagi daearah ini untuk mempunyai pertumbuhan ekonomi yang memuaskan di masa-masa mendatang. Di tahun 2009, lebih dari setengah (55 persen) dari angkatan kerja di Jawa Timur hanya memiliki pendidikan sekolah dasar atau lebih rendah, termasuk 21 persen dari seluruh angkatan kerja yang tidak pernah mengenyam pendidikan di sekolah atau tidak menyelesaikan sekolah dasar. Hanya sekitar 6 persen dari angkatan kerja pernah mengenyam pendidikan lanjutan setelah sekolah menengah. Mayoritas kualitas tenaga kerja tidak terampil dipekerjakan pada sektor pertanian yang memiliki tingkat produktivitas yang rendah. Para pekerja di sektor ini mendapat upah yang paling rendah. Sekitar 52 persen dari pekerja pertanian berada pada kelompok umur yang lebih tinggi (di atas 40 tahun) dengan sekolah dasar sebagai tingkat pendidikan tertinggi yang pernah dikecap. 


\section{Jumlah dan Persentase Penduduk Yang Bekerja di Jawa Timur Menurut Pendidikan dan Lapangan Usaha Tahun 2010}

\begin{tabular}{|c|c|c|c|c|c|c|c|c|c|c|}
\hline \multirow{2}{*}{ PENDIDIKAN } & \multicolumn{9}{|c|}{ LAPANGAN USAHA } & \multirow{2}{*}{ JUMLAH } \\
\hline & 1 & 2 & 3 & 4 & 5 & 6 & 7 & 8 & 9 & \\
\hline$\angle S D$ & 6.302 .681 & 96.782 & 1.027 .451 & 2.129 & 466.423 & 1.670 .597 & 345.014 & 16.892 & 597.032 & 10.525 .001 \\
\hline SMP & 1.117 .227 & 18.885 & 594.605 & 4.387 & 241.386 & 849.651 & 166.106 & 47.947 & 385.762 & 3.425 .956 \\
\hline SMA Umum & 328.494 & 9.525 & 417.869 & 10.137 & 84.048 & 713.649 & 130.793 & 66.645 & 459.292 & 2.220 .452 \\
\hline SMA Kejuruan & 156.373 & 6.840 & 348.476 & 6.577 & 77.696 & 403.541 & 86.444 & 35.277 & 289.922 & 1.411 .146 \\
\hline \begin{tabular}{|l|} 
Diploma I/II/III/ \\
Akademi \\
\end{tabular} & 10.191 & 284 & 28.837 & 526 & 4.257 & 56.640 & 6.961 & 17.537 & 154.242 & 279.475 \\
\hline Universitas & 24.514 & 1.576 & 65.325 & 1.909 & 20.838 & 93.702 & 20.265 & 47.702 & 559.247 & 835.078 \\
\hline Jumlah & 7.939 .480 & 133.892 & 2.482 .563 & 25.665 & 894.648 & 3.787 .780 & 755.583 & 232.000 & 2.445 .497 & 18.697 .108 \\
\hline
\end{tabular}

\begin{tabular}{|c|c|c|c|c|c|c|c|c|c|c|}
\hline \multirow{2}{*}{ PENDIDIKAN } & \multicolumn{9}{|c|}{ LAPANGAN USAHA } & \multirow{2}{*}{ JUMLAH } \\
\hline & 1 & 2 & 3 & 4 & 5 & 6 & 7 & 8 & 9 & \\
\hline$\angle S D$ & $33,71 \%$ & $0,52 \%$ & $5,50 \%$ & $0,01 \%$ & $2,49 \%$ & $8,94 \%$ & $1,85 \%$ & $0,09 \%$ & $3,19 \%$ & $56,29 \%$ \\
\hline SMP & $5,98 \%$ & $0,10 \%$ & $3,18 \%$ & $0,02 \%$ & $1,29 \%$ & $4,54 \%$ & $0,89 \%$ & $0,26 \%$ & $2,06 \%$ & $18,32 \%$ \\
\hline SMA Umum & $1,76 \%$ & $0,05 \%$ & $2,23 \%$ & $0,05 \%$ & $0,45 \%$ & $3,82 \%$ & $0,70 \%$ & $0,36 \%$ & $2,46 \%$ & $11,88 \%$ \\
\hline SMA Kejuruan & $0,84 \%$ & $0,04 \%$ & $1,86 \%$ & $0,04 \%$ & $0,42 \%$ & $2,16 \%$ & $0,46 \%$ & $0,19 \%$ & $1,55 \%$ & $7,55 \%$ \\
\hline $\begin{array}{l}\text { Diploma I/II/III/ } \\
\text { Akademi }\end{array}$ & $0,05 \%$ & $0,00 \%$ & $0,15 \%$ & $0,00 \%$ & $0,02 \%$ & $0,30 \%$ & $0,04 \%$ & $0,09 \%$ & $0,82 \%$ & $1,49 \%$ \\
\hline \begin{tabular}{|l|} 
Universitas \\
\end{tabular} & $0,13 \%$ & $0,01 \%$ & $0,35 \%$ & $0,01 \%$ & $0,11 \%$ & $0,50 \%$ & $0,11 \%$ & $0,26 \%$ & $2,99 \%$ & $4,47 \%$ \\
\hline Jumlah & $42,46 \%$ & $0,72 \%$ & $13,28 \%$ & $0,14 \%$ & $4,78 \%$ & $20,26 \%$ & $4,04 \%$ & $1,24 \%$ & $13,08 \%$ & $100,00 \%$ \\
\hline
\end{tabular}

Sumber: BPS. Survey Angkatan Kerja Nasional. Agustus 2010, diolah Pusdatinaker

Keterangan:

1: Pertanian, kehutanan, perkebunan dan perikanan, 2:Pertambangan dan pengolahan, 3: Industri Pengolahan, 4: Listrik, Gas dan air, 5: bangunan, 6: Perdagangan besar,eceran, rumah makan dan hotel, 7: Angkutan, pergudangan dan komunikasi, 8: Keuangan, asuransi, usaha persewaan bangunan, tanah dan jasa perusahaan, 9: Jasa kemasyarakatan.

Hal tersebut seperti ditunjukkan oleh data yang dirilis oleh BPS dalam Survey Angkatan Kerja Nasional berikut. Banyaknya tenaga kerja yang terserap dalam sektor pertanian pada tahun 2010 sangat mendominasi, yaitu sebesar 7.939.480 orang atau sebesar $42,46 \%$. Jika dilihat berdasarkan jenjang pendidikan, banyaknya kualitas tenaga kerja dengan pendidikan SD yang terserap di sektor pertanian adalah sebesar 6.302.681 orang atau sebesar $33,71 \%$, jenjang SMP sebesar 1.117.227 orang $(5,98 \%)$, SMA umum sebesar 328.494 orang (1,76\%), SMA Kejuruan sebesar 156.373 orang $(0,84 \%)$, Diploma I/II/III/ Akademi 10.191 orang $(0,05 \%)$ dan Universitas sebesar 24.514 orang $(0,13 \%)$. Sehingga kualitas tenaga kerja tersebut di sektor pertanian tidak membutuhkan ketarampilan / skill yang tinggi dalam pendidikan formal.

Hambatan utama untuk memiliki lebih banyak angkatan kerja yang lebih terampil adalah rendahnya akses terhadap pendidikan menengah, yang menyebabkan rendahnya capaian pendidikan di provinsi tersebut. Terdapat jurang yang lebar antara kaum berada dan kaum miskin, dan juga antara penduduk pedesaan dan perkotaan dalam hal akses terhadap pendidikan menengah. Akses yang timpang ini dapat disebabkan oleh terbatasnya jumlah sekolah menengah, distribusi sekolah yang tidak merata dan relatif tingginya biaya pendidikan menengah. Di tahun 2005/2006, angka partisipasi murni di Jawa Timur berada pada 97,24 persen untuk tingkat dasar, 71,22 persen untuk menengah pertama dan 42,56 persen bagi tingkat menengah atas.

Tren ini serupa dengan angka partisipasi murni di Indonesia, dimana angka partisipasi bagi tingkat menengah pertama dan menengah atas masih jauh dari tingkat universal. Di tingkat kabupaten/kota, banyak kabupaten/kota mencatat angka partisipasi murni sekolah dasar di atas 90 persen. Akan tetapi variasi angka partisipasi yang lebih besar dapat dijumpai pada tingkat menengah pertama 
dan menengah atas. Sebagai contoh, tingkat angka partisipasi murni di Kota Kediri adalah 112,75 persen (APM Tahun 2005/2006), sementara Kabupaten Sampang hanya mencatat 45,63 persen.

Dalam rangka untuk mengatasi masalah kualitas tenaga kerja seperti tersebut di atas, maka pemberian akses yang lebih besar bagi pendidikan menengah dapat meningkatkan jumlah pekerja terampil di provinsi Jatim. Hal ini dapat dicapai dengan meningkatkan alokasi dana bagi pendidikan menengah dan juga memperluas dan mengoptimalkan sekolah-sekolah kejuruan dan lembaga pendidikan non formal.

Berikut adalah model peningkatan produktivitas menuju keunggulan kompetitif yang bisa di jadikan acuan oleh pemerintah Provinsi Jawa Timur. Model ini diambil berdasarkan Masterplan Percepatan Dan Perluasan Pembangunan Ekonomi Indonesia 2011 s.d 2025.

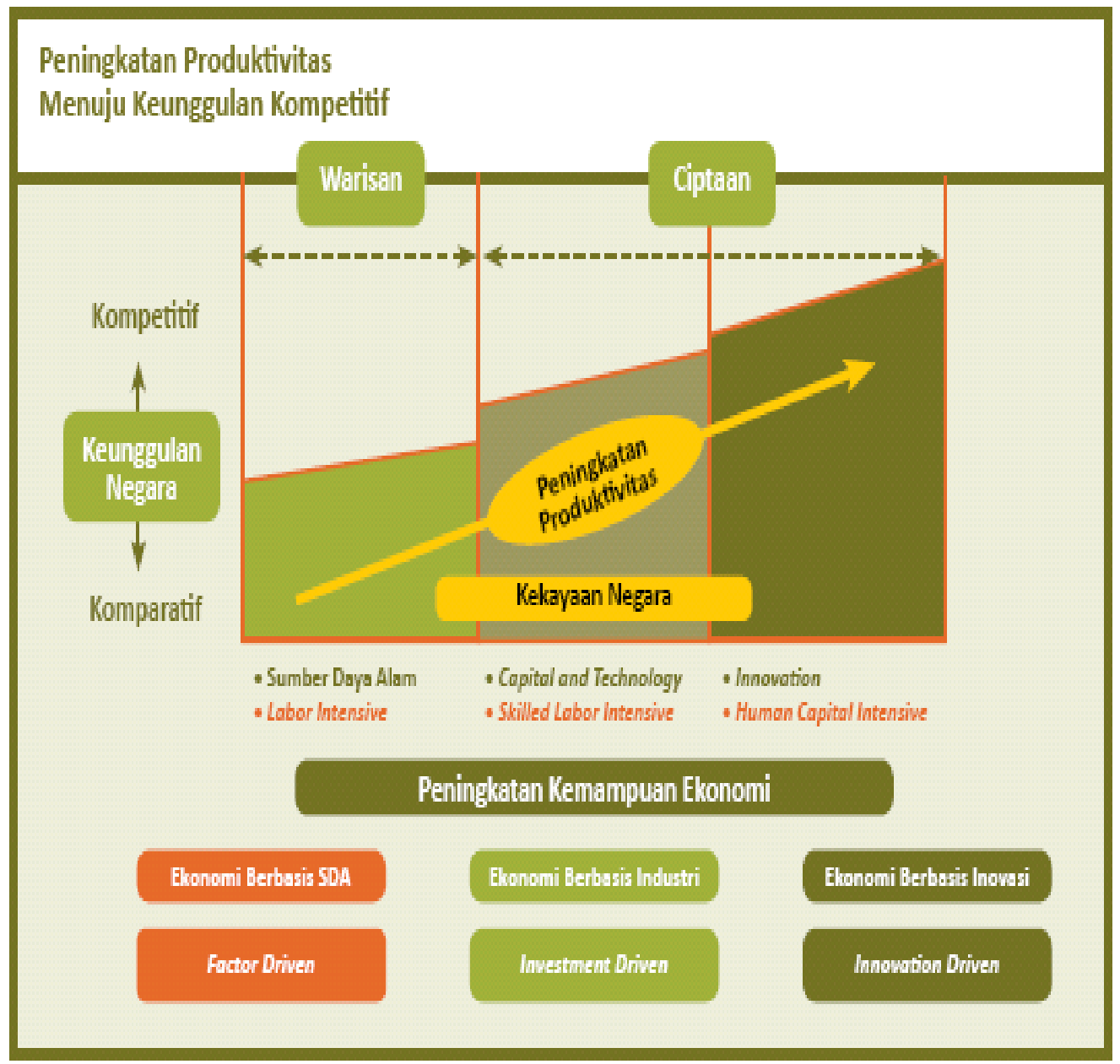

Model Peningkatan Produktivitas Menuju Keunggulan Kompetitif

Sumber: Masterplan Percepatan Dan Perluasan Pembangunan Ekonomi Indonesia 2011 s.d 2025 


\begin{tabular}{|c|c|c|c|}
\hline $\begin{array}{l}\text { 1\% dari GDP } \\
\text { per tahun }\end{array}$ & $\begin{array}{l}7 \text { Langkah Perbaikan } \\
\text { Ekosistem Inovasi }\end{array}$ & $\begin{array}{l}4 \text { Wahana Percepatan } \\
\text { Pertumbuhan Ekonomi }\end{array}$ & 7 Sasaran VISI Inovasi 2025 \\
\hline $\begin{array}{l}\text { Untuk menunjang } \\
\text { program inovasi } \\
\text { melalui skema } 747 \\
\text { diperlukan dana R\& } \\
\text { D hingga } 1 \% \text { dari GDP } \\
\text { per tahun s/d tahun } \\
2014 \\
\text { Peningkatan tersebut } \\
\text { dapat dilaksanakan } \\
\text { secara bertahap } \\
\text { sesuai dengan daya } \\
\text { dukung pemerintah, } \\
\text { BUMN dan partisipasi } \\
\text { swasta }\end{array}$ & $\begin{array}{l}\text { 1. Sistem insentif dan regulasi yang } \\
\text { mendukung inovasi dan budaya } \\
\text { penggunaan produk dalam negeri } \\
\text { 2. Peningkatan Kualitas dan } \\
\text { Fleksibilitas perpindahan sumber } \\
\text { daya manusia } \\
\text { 3. Pembangunan Pusat-pusat inovasi } \\
\text { untuk mendukung IKM } \\
\text { 4. Pembangunan Klaster Inovasi } \\
\text { Daerah } \\
\text { 5. Sistem Remunerasi Peneliti } \\
\text { 6. Revitalisasi Infrastruktur R \& D } \\
\text { 7. Sistem dan Manajemen } \\
\text { Pendanaan Riset yang mendukung } \\
\text { Inovasi }\end{array}$ & $\begin{array}{l}\text { 1. Industri kebutuhan } \\
\text { dasar (pangan, obat- } \\
\text { obatan, energi dan air } \\
\text { bersih) } \\
\text { 2. Industri kreatif } \\
\text { (berbasis budaya dan } \\
\text { digital content) } \\
\text { 3. Industri berbasis daya } \\
\text { dukung daerah Science } \\
\text { \& Technology (S \& T) } \\
\text { Park \& Industrial Park } \\
\text { 4. Industri strategis } \\
\text { (pertahanan, } \\
\text { transportasi, dan ICT) }\end{array}$ & $\begin{array}{l}\text { 1. Meningkatkan jumlah HaKI dari penelitian dan industri } \\
\text { yang langsung berhubungan dengan pertumbuhan } \\
\text { ekonomi } \\
\text { 2. Meningkatkan infrastruktur S \& T Park berstandar } \\
\text { internasional } \\
\text { 3. Mencapai swasembada pangan, obat-obatan, energi dan } \\
\text { air bersih yang berkesinambungan } \\
\text { 4. Meningkatkan ekspor produk industri kreatif menjadi dua } \\
\text { kali lipat } \\
\text { 5. Meningkatkan jumlah produk-produk unggulan dan nilai } \\
\text { tambah industri dari berbagai daerah } \\
\text { 6. Mencapai swasembada produk dan sistem industri } \\
\text { pertahanan, transportasi dan ICT } \\
\text { 7. Mencapai pertumbuhan ekonomi yang berkesinambungan, } \\
\text { kemakmuran yang merata, dan memperkokoh NKRI }\end{array}$ \\
\hline
\end{tabular}

Inisiatif Inovasi : 1 -747 MP3EI

Sumber: Masterplan Percepatan Dan Perluasan Pembangunan Ekonomi Indonesia 2011 s.d 2025

Untuk mewujudkan peningkatan produktivitas, maka direkomendasikan usulan Inisiatif Inovasi 1-747 MP3EI sebagai pendorong utama terjadinya proses transformasi sistem ekonomi berbasis inovasi melalui penguatan sistem pendidikan (human capital) dan kesiapan teknologi (technological readiness). Proses transformasi tersebut memerlukan input pendanaan Penelitian dan Pengembangan ( $\mathrm{R} \& \mathrm{D}$ ) sebesar 1 persen dari GDP yang perlu terus ditingkatkan secara bertahap sampai dengan 3 persen GDP menuju 2025. Porsi pendanaan penelitian dan pengembangan tersebut diatas, berasal dari Pemerintah maupun dunia usaha. Pelaksanaannya dilakukan melalui 7 langkah perbaikan ekosistem inovasi, sedangkan prosesnya dilakukan dengan menggunakan 4 wahana percepatan pertumbuhan ekonomi sebagai model penguatan aktor-aktor inovasi yang dikawal dengan ketat. Dengan demikian diharapkan 7 sasaran visi inovasi 2025 di bidang SDM dan IPTEK akan dapat tercapai sehingga menjamin percepatan dan perluasan pembangunan ekonomi yang berkelanjutan. Seiring dengan kemajuan ekonomi dari faktor driven economy menuju ke innovation driven economy, diharapkan peran pemerintah di dalam pendanaan $\mathrm{R} \& \mathrm{D}$ akan semakin berkurang dan sebaliknya peran swasta semakin meningkat.

\section{KESIMPULAN}

Berikut ini adalah beberapa inisiatif pelaksanaan inovasi yang dapat mendukung keberhasilan implementasi seperti tersebut di atas:

1. Pengembangan Klaster Inovasi untuk mendukung koridor ekonomi di Jawa Timur.

Pengembangan koridor ekonomi harus diiringi dengan penguatan klaster inovasi sebagai centre of excellence dalam rangka mendukung peningkatan kemampuan berinovasi untuk meningkatkan daya saing. Pengembangan centre of excellence tersebut diharapkan terintegrasi dengan klaster-klaster industri.

2. Revitalisasi PUSPIPTEK sebagai Science \& Technology (S\&T) Park Merevitalisasi PUSPIPTEK sebagai $\mathrm{S} \& \mathrm{~T}$ Park bertujuan untuk melahirkan IKM/UKM berbasis inovasi dalam berbagai bidang strategis yang mampu mengoptimalkan interaksi dan pemanfaatan sumber daya universitas, lembaga litbang, dan 
dunia usaha sehingga dapat menghasilkan produk inovatif. Untuk menjaga keberlanjutan pengelolaan $\mathrm{S} \& \mathrm{~T}$ Park tersebut perlu dilakukan:

a. Menjadikan PUSPIPTEK sebagai Badan Layanan Umum (BLU) dengan manajemen profesional sehingga tercipta link antara bisnis dan riset;

b. Menjadikan PUSPIPTEK sebagai pusat unggulan riset berteknologi tinggi.

3. Pembentukan Klaster Inovasi Daerah untuk Pemerataan Pertumbuhan

Pemerintah Provinsi Jawa Timur dapat mendorong dan memberdayakan upaya masyarakat, pelaku usaha, pemerintah daerah yang sudah memiliki inisiatif untuk menumbuh-kembangkan potensi inovasi pada beberapa produk dan program unggulan wilayah, antara lain:

a. Model Pengembangan Kawasan Inovasi Agroindustri, di Gresik Utara Provinsi Jawa Timur;

b. Model pengembangan kawasan industri inovasi produk-produk hilir yang terintegrasi, untuk pengembangan kelapa sawit, kakao, dan perikanan;

c. Model Pengembangan Kawasan Inovasi Energi yang berbasis non-renewable dan renewable energy di Provinsi Kalimantan Timur.

\section{DAFTAR PUSTAKA}

Arsyad, Lincolin,1998. Ekonomi Pembangunan. Edisi kedua, Yogyakarta: BPFE-Yogyakarta
Baltagi, Budi H 2005. Econometric Analysis of Panel Data. Third Edition. Chichester: Jhon Wiley and sons.

Bank Dunia Dan International Finance Corporation. 2010.Doing Bussiness di Indonesia 2010:Memperbandingkan

Kebijakan Usaha di 14 kota dan 183 Perekonomian. Washington, DC : Publikasi Bank Dunia dan International Finance Corporation. ,2000. Ekonomi Makro. Yogyakarta: BPFE-Yogyakarta. Boediono,1999. Ekonomi Makro. Yogyakarta: BPFE-Yogyakarta.

Borensztein, E. \& De Gregorio, J. \& Lee, J-W., 1998. "How does foreign direct investment affect economic growth?," Journal of International Economics, Elsevier, vol. 45(1), pages 115-135, June.

Brian J. Aitken \& Ann E. Harrison, 1999. "Do Domestic Firms Benefit from Direct Foreign Investment? Evidence from Venezuela," American Economic Review, American Economic Association, vol. 89(3), pages 605-618, June.

Carcovic, Mario and Levine, Ross. 2004. Does Foreign Direct Investment accelerate Economic Growth?. Published on The Institute of International Economics Confereences. Washington.

Chenery, Hollis B. And Carter, Nicholas G. 1973. Foreign Assistance and Development Performance, 19601970. The American Economic Review (AER), 63(2), 459 - 68.

Dajan, Anto. 1984. Pengantar Metode Statistik. Jilid 2. Jakarta: LP3ES.

Gujarati,Domodar N.2003. Basic Econometrics. Fourth Edition. New York: The McGraw-Hill Companies.

---------. 1995. Ekonometrika Dasar. Jakarta: Erlangga. 
Haddad, M. and A. Harrison, 1993, "Are there Positive Spillovers from Direct Foreign Investment?", Journal of Development Economics, Vol. 42, pp. 51-74.

Irwan dan Suparmoko,1992. Ekonomika Pembangunan. Edisi lima, Yogyakarta: BPFE-Yogyakarta.

Ismet, Johar. 1996. "Analisis Pertumbuhan Ekonomi Dan Distribusi Pendapatan Masyarakat Kota Batam Dengan Pendekatan Model System Neraca Sosial Ekonomi (SNSE)," online),(diakses tanggal 30 Maret 2010)

Kelley, C. Allen dan Robert M. Schmidt.1995. "Aggregate

Population and Economic Growth Corelation: The role of the components of demographic changes" (online),(diakses tanggal 21 Maret 2010)

Kementerian Koordinator Bidang Perekonomian. 2011. Masterplan Percepatan dan Perluasan Pembangunan Ekonomi Indonesia. Jakarta: Kementerian Koordinator Bidang Perekonomian, Deputi Bidang Infrastruktur dan Pengembangan Wilayah Kementerian Koordinator Bidang Perekonomian

Kobrin, S.J. 1977. "Foreign Direct Investments, Industrialization, and Social Change", Jai Press, Connecticut.

Kuncoro, Mudrajat. 2000. "Ekonomi Pembangunan: Teori, Masalah dan Kebijakan", UPP AMP YKPN, Yogyakarta.

Kuntjoro Jakti, Dorojatun,2003. Mau kemana Pembangunan Ekonomi Indonesia. Jakarta: Prenada Media.

Lembaga Penyelidikan Ekonomi Masyarakat (LPEM). 2007. Construction of Regional Index of
Cost of Doing Business in Indonesia

Lipsey, Richard G dkk, 1991. Pengatar Makro Ekonomi. Edisi kedelapan, Jakarta: Erlangga.

Magnus Blomstrom \& Robert E. Lipsey \& Mario Zejan, 1994. "What Explains Developing Country Growth?," NBER Working Papers 4132, National Bureau of Economic Research, Inc.

Mishkin, Frederich.1996. "The Channels of Monetary Transmission : Lesson for Monetary Policy" .National Bureau of Economic Research Working Paper vol 5464: 2

Mubyarto. 2003. " Teori Investasi dan Pertumbuhan Ekonomi Dalam Ekonomi Pancasila ". Jurnal Ekonomi Rakyat. Edisi 16: 4

Noerdhaus dan samuelson, 2000. Ilmu Makro Ekonomi. Jakarta: Media Global Edukasi.

Pujiati, Amin.2007. "Analisis Pertumbuhan Ekonomi Di Karesidenan Semarang Era Desentralisasi Fiskal " Jurnal Pembangunan. (Online),hal: $61-$

70,(http://uns.ac.id/ejournal/ind ex.php/aku/article/viewPDFInte rstitial/15656/15648/, diakses 20 Januari 2010)

Rosyidi, Suherman.2000. Pengantar Ilmu Ekonomi. Jakarta:Erlangga.

Sadli, M, (2002), "Beberapa Masalah Dalam Ekonomi Makro”, Modul Pelatihan Training Manajer BRI, Jakarta.

Samuelson, Paul A dan William

D.Nordhaus.2001."Ilmu

Makroekonom ".Edisi Tujuh

Belas.Terjemahan .Jakarta:PT

Media Global Edukasi.

Sarwoko, 2005. Dasar-Dasar ekonometrika. Yogyakarta: Andi.

Sitompul,novita linda.2007. analisis pengaruh investasi dan tenaga kerja terhadap PDRB Sumatra Utara.Tesis tidak 
diterbitkan.Medan: pasca Sarjana Universitas sumatra utara.

Sodik, Jamzani,dkk. 2005. "Investasi, Pendidikan Tenaga Kerja Dan Pertumbuhan Ekonomi Regional (Studi Kasus Pada 26 Propinsi Di Indonesia, Pra Dan Pasca Otonomi)"Jurnal Ekonomi Pembangunan.

(Online),vol.10,No.2(http://upn.a c.id/ejournal/ article / view PDF Interstitial/, diakses 20 Januari 2010)

Sukirno, Sadono.1981. Pengantar Teori Makroekonomi. Jakarta: Bima Grafika

1981. Pengantar Teori Makroeskonomi. Jakarta: Bima Grafika

1985. Ekonomi Pembangunan Proses, Masalah dan Dasar Kebijaksanaan. Jakarta: Fakultas Ekonomi UI dengan Bima Grafika.

--------.2004. Makroekonomi Teori Pengantar. Jakarta: Bima Grafika.

Suparmoko.1996. Pengantar Ekonometrika Makro. Edisi ketiga, Yogyakarta: BPFEYogyakarta

Syamsiyah, Siti. 2007. “Analisis Kualitas Tenaga Kerja Dan Investasi Terhadap Pertumbuhan Ekonomi Kabupaten Karanganyar'. skripsi yang diterbitkan (http://ums.com/skrispsi/article/vi ewPDFInterstitial/,diakses 19 Januari 2010)

Tarmidi,T Lepi.1992. Ekonomi Pembangunan. Jakarta: Fakultas Ekonomi UI.

Verbeek, Marno.2000. A Guide to Modern econometrics. Chicherster:Jhon Wiley and sons.

Widarjono, Agus.2005. Ekonometrika Teori dan Aplikasi. Yogyakarta: Ekonisia Fakultas ekonomi UII

Winoto, Joyo,2000,ekonomi pembangunan. Bahan bacaan tambahan mata kuliah perencanaan ekonomi wilayah dan pedesaan. Program studi ilmu prencanaan pembangunan wilayah dan pedesaan program pascasarjana IPB.

Worldbank. 2011. Perkembangan Triwulanan Perekonomian Indonesia: Tantangan saat ini, peluang masa depan. Jakarta: Juni 2011

Worldbank. 2011. Perkembangan Triwulanan Perekonomian Indonesia: Masa Bergejolak. Jakarta: Oktober 2011

www.BPS.go.id 